\title{
INFLUENCE OF ASCORBIC ACID ON EGG QUALITY ${ }^{1}$
}

\author{
Pedro Alves de SOUZA ${ }^{2, *}$, Hirasilva Borba Alves de SOUZA², Alexandre OBA², \\ Claudio Henrique Cruz GARDINI ${ }^{2}$
}

\begin{abstract}
SUMMARY
The egg quality may be influenced by some nutrients added to laying hens diets and among these nutrients, the ascorbic acid is included. According to some researches, this acid, besides of improving the quality, it can increase the egg production and weight. In addition, it reduces the quantity of cracked eggs and food intake. In order to contribute with more information, this experiment was developed. Concentrations of $100 ; 150$ and $200 \mathrm{mg} / \mathrm{kg}$ of ascorbic acid were added to rations of laying hens during 60 days, with the objective of determining the influence of ascorbic acid on the quality of eggs kept under room temperature conditions $(26.7 \pm$ $2.2^{\circ} \mathrm{C}$ and $60 \pm 5 \%$ moisture) for a period of 28 days. A total of 1440 eggs were used, being 720 of white shell and 720 of brown shell. Egg quality was determined by Haugh unit and yolk index, every 7 days. The obtained results allowed to conclude that ascorbic acid, independent on the level of supplementation, was not enough to decrease.
\end{abstract}

Keywords: ascorbic acid; eggs; quality; laying hens.

\section{RESUMO}

INFLUÊNCIA DO ÁCIDO ASCÓRBICO NA QUALIDADE DO OVO. A qualidade dos ovos pode ser influenciada por alguns nutrientes adicionados à dieta das aves e entre esses nutrientes se inclui o ácido ascórbico, que segundo alguns pesquisadores, além de melhorar a qualidade, pode aumentar a produção e o peso dos ovos e diminuir a quantidade de ovos trincados e o consumo de ração. Com a finalidade de tentar contribuir com mais algumas informações, desenvolveu esse experimento com o objetivo de avaliar a influência do ácido ascórbico sobre a qualidade de ovos brancos e marrons mantidos sob condições de ambiente $\left(26,7 \pm 2,2^{\circ} \mathrm{C}\right.$ e $60 \pm 5 \%$ UR), por um período de 28 dias. Foram utilizados 1440 ovos, sendo 720 de casca branca e 720 de casca marrom. Foram adicionadas à ração de aves, durante 60 dias, concentrações de 100, 150 e 200mg/kg de ácido ascórbico. A qualidade dos ovos foi determinada de $7 \mathrm{em} 7$ dias, avaliando-se a unidade Haugh e o índice gema. Os dados obtidos permitiram concluir que a suplementação com o ácido ascórbico não foi suficiente para diminuir a perda de qualidade dos ovos. Independentemente dos níveis de vitaminas utilizados, os ovos marrons mostraram-se qualitativamente superiores aos brancos.

Palavras-chave: poedeiras; ácido ascórbico; ovos; qualidade.

\section{1 - INTRODUCTION}

The ascorbic acid utilization in laying food has been purpose of several scientific meetings. The acceptance of this vitamin in commercial transactions continues

${ }^{1}$ Recebido para publicação em 26/10/99. Aceito para publicação em 08/08/01.

${ }^{2}$ Departament of Technology - Faculdade de Ciências Agrárias e Veterinárias-UNESP - Campus de Jaboticabal - Via de Acesso Prof. Paulo Donato Castellane, km 5 - CEP 14870-000 Jaboticabal-SP - Brasil.

${ }^{*}$ A quem a correspondência deve ser enviada. improving, despite most of the producers haven't obtained the benefits in daily production linked by sale business. A good feed must provide the organism with all the necessary nutritive elements. It is usually based on a high consumption of fruits, green vegetables and protein of animal origin. Eggs when consumed in good conditions, they have a pleasant flavor and a high nutritional quality. Eggs besides being rich in minerals and vitamins; they present in average: $12.14 \mathrm{~g} / 100 \mathrm{~g}$ of protein, $1.20 \mathrm{~g} / 100 \mathrm{~g}$ of carbohydrates and $11.15 \mathrm{~g} / 100 \mathrm{~g}$ of lipids.

Due to their high nutritional value, allied to a low price, in comparison to other animal products, they are highly indicated to alleviate nutritional problems in low income populations. But in order to improve their accessibility to populations there is a need to increase quality indexes related to their preservation. Egg quality is determined by the parameter Haugh unit.

Ascorbic acid supplementation of the diet of laying hens reduced the incidence of stress [1, 5, 10, 13], it increased the production and improved egg quality [2, 3, 6, 7, 8, 11, 12]. Though, KECHICK, SYKES [4] did not find any relationship between ascorbic acid supplementation of rations and productive and qualitative parameters of the produced eggs.

The objective of this work was to study the influence diet supplementation with of ascorbic acid on the qualitative parameters of white and brown eggs, maintained for 28 days under room temperature conditions $\left(26.7 \pm 2.2^{\circ} \mathrm{C}\right.$ and $60 \pm 5 \%$ moisture $)$.

\section{2 - MATERIAL AND METHODS}

\section{1 - Treatments}

Two thousand laying hens (1000 Hy-line white and $1000 \mathrm{Hy}$-line brown) were fed with diets supplemented with 100,150 and $200 \mathrm{mg} / \mathrm{kg}$ of ascorbic acid C for 60 days.

\section{2 - Biological material}

A total of 1440 eggs (720 of white shell and 720 of brown shell) were obtained after a selection and a standardization around $63 \pm 2 \mathrm{~g}$. It was used three eggs for each analysis.

\section{3 - Experimental design}

The experimental design used was randomized blocks in a $2 \times 4$ factorial design (color of shells $x$ levels of supplementation) with 6 repetitions and 30 eggs for experimental unit. The obtained means were compared by the test of Tukey at $5 \%$ of probability. 


\section{4 - Evaluations}

Egg quality was determined by Haugh unit and yolk index, every weekly, during 28 days according to SOUZA et al. [9], which is determined through the equation: $\mathrm{UH}=100 \mathrm{Log}(\mathrm{H}+7.57-1.7 \mathrm{~W} 0.37)$, where $\mathrm{UH}=$ Haugh unit, $\mathrm{H}=$ height of the albumen and $\mathrm{W}=$ weigh of the egg. The yolk index by means of the following relationship: $\mathrm{YI}=\mathrm{YW} / \mathrm{YD}$, where $\mathrm{YI}=$ yolk index, $T Y=$ thickness of the yolk and $D Y=$ diameter of the yolk.

\section{3 - RESULTS AND DISCUSSION}

The results obtained for Haugh unit and yolk index are presented in Tables 1 and 2. It can be verified (Table 1 ) that during room temperature storage, in the beginning of the storage $\left(1^{\text {st }}\right.$ day) there were not significant differences between eggs of white shell and those of brown shell. But with time of storage brown eggs presented significantly superior values for Haugh unit $(p<0,05)$ than white shell eggs. Ascorbic acid supplementation was significantly noted in the beginning ( $1^{\text {st }}$ day) and at the end ( $28^{\text {th }}$ day) of storage, i.e. eggs coming from birds that did not receive supplementation presented Haugh unit values, significant lower than the other treatments. This low quality remained significant along the storage period only in comparison with eggs that came from birds that received $200 \mathrm{mg} / \mathrm{kg}$ of ascorbic acid. After 7 , 14 days of storage, the supplementation of $200 \mathrm{mg} / \mathrm{kg}$ of ascorbic acid presented significant higher means than the other treatments. For the $21^{\text {st }}$ and $28^{\text {th }}$ day of storage no significant differences were found among treatments. Although it hasn't avoided the loss of yolk quality, rated through the yolk index during the storage, the ascorbic acid utilization propitiated results significantly higher than the control diet during all period of storage eggs. There wasn't a significant difference among the different ascorbic acid levels utilized. However, the concentration of $200 \mathrm{mg} / \mathrm{kg}$ showed better yolk indices. Comparing brown and white eggs, it can be checked that higher yolk indices in brown eggs. These results are similar to those obtained and described by CHENG, COON, HAMRE [1] and RODRIGUES BERTECHINI, OLIVEIRA [8] that did not find positive effects of ascorbic acid supplementation of diets of birds in posture on the qualitative parameters of the eggs. However, these results disagree from those presented by KECHICK, SKYRES [4] that detect differences on egg quality when birds diets were supplemented with ascorbic acid.

When white shell eggs are compared with brown shell eggs in each supplementation level, it can be observed that initial non existent differences became evident and significantly present with the increase of the storage period.

The variation in the quality of the yolk, measured by the yolk index (Table 2) evidenced a significant $(p<0,05)$ superiority of brown eggs in relation to white ones in the whole storage period. Supplementation with ascorbic acid did not have influence on this index at the beginning of the experiment ( $1^{\text {st }}$ day) and after 21 days of storage. At 7 and 14 days of storage, the best results for yolk index were obtained with the check and supplementation of $100 \mathrm{mg} / \mathrm{kg}$ of ascorbic acid.

TABLE 1. Variation in quality of white and brown eggs, measured by the Haugh unit produced by laying hens, submited to improved diets with different ascorbic acid levels, are stored under room temperature conditions $\left(26.7 \pm 2.2^{\circ} \mathrm{C}\right.$ and $60 \pm 5 \%$ moisture).

\begin{tabular}{cccccc}
\hline $\begin{array}{c}\text { Supplementary } \\
\text { Levels of } \\
\text { Vitamin C }\end{array}$ & \multicolumn{5}{c}{ Haugh unit $^{(1)}$} \\
\cline { 2 - 6 } & \multicolumn{5}{c}{ Storage periods (days) } \\
\cline { 2 - 6 } & $82,40 \mathrm{~b}^{(1)}$ & $49,00 \mathrm{~b}$ & $28,84 \mathrm{ab}$ & $16,67 \mathrm{~b}$ & $13,84 \mathrm{~b}$ \\
\hline 0 & $85,30 \mathrm{a}$ & $47,70 \mathrm{~b}$ & $26,38 \mathrm{~b}$ & $20,53 \mathrm{ab}$ & $20,16 \mathrm{a}$ \\
100 & $85,40 \mathrm{a}$ & $46,60 \mathrm{~b}$ & $25,48 \mathrm{~b}$ & $19,40 \mathrm{ab}$ & $20,62 \mathrm{a}$ \\
150 & $85,90 \mathrm{a}$ & $53,30 \mathrm{a}$ & $31,58 \mathrm{a}$ & $21,82 \mathrm{a}$ & $21,94 \mathrm{a}$ \\
200 & $85,05 \mathrm{a}$ & $46,25 \mathrm{~b}$ & $26,08 \mathrm{~b}$ & $19,12 \mathrm{~b}$ & $14,13 \mathrm{~b}$ \\
White Shells & $84,45 \mathrm{a}$ & $52,05 \mathrm{a}$ & $30,06 \mathrm{a}$ & $24,16 \mathrm{a}$ & $20,59 \mathrm{a}$ \\
Brown Shells & 2,27 & 6,73 & 13,07 & 12,08 & 20,94 \\
C.V.(\%) & & & & & \\
\hline
\end{tabular}

(1)Means in the same column followed by the same letter they do not differ by test (1)Means in the same column
of Tukey at $5 \%$ of probability.

TABLE 2. Variation in quality of white and brown eggs, measured by the yolk index $(x 100)$ produced by laying hens submited to improved diets iwith different ascorbic acid levels, are stored under room temperature conditions $\left(26.7 \pm 2.2^{\circ} \mathrm{C}\right.$ and $60 \pm 5 \%$ moisture).

\begin{tabular}{cccccc}
\hline $\begin{array}{c}\text { Supplementary } \\
\text { Levels of } \\
\text { Vitamin C }\end{array}$ & \multicolumn{5}{c}{ Yolk index $(\mathrm{x} 100)^{(1)}$} \\
\cline { 2 - 6 } & \multicolumn{5}{c}{ Storage periods (days) } \\
\cline { 2 - 6 } & $45,00 \mathrm{a}^{(1)}$ & $35,20 \mathrm{a}$ & $24,90 \mathrm{ab}$ & $20,80 \mathrm{a}$ & $15,70 \mathrm{a}$ \\
\hline 0 & $46,20 \mathrm{a}$ & $33,80 \mathrm{ab}$ & 26,00 & $21,40 \mathrm{a}$ & $16,80 \mathrm{a}$ \\
100 & $45,10 \mathrm{a}$ & $33,20 \mathrm{~b}$ & $24,00 \mathrm{~b}$ & $20,90 \mathrm{a}$ & $15,90 \mathrm{a}$ \\
150 & $45,70 \mathrm{a}$ & $34,50 \mathrm{ab}$ & $24,00 \mathrm{~b}$ & $20,40 \mathrm{a}$ & $15,60 \mathrm{a}$ \\
200 & $43,86 \mathrm{~b}$ & $32,55 \mathrm{~b}$ & $23,95 \mathrm{~b}$ & $20,05 \mathrm{~b}$ & $15,35 \mathrm{~b}$ \\
White shells & $47,50 \mathrm{a}$ & $35,80 \mathrm{a}$ & $25,50 \mathrm{a}$ & $21,70 \mathrm{a}$ & $16,65 \mathrm{a}$ \\
Brown shells & 3,78 & 3,91 & 5,56 & 6,91 & 8,34 \\
C.V.(\%) & & & & \\
\hline
\end{tabular}

(1) Means in the same column followed by the same letter they do not differ by test of Tukey at $5 \%$ of probability.

\section{4 - CONCLUSIONS}

From the obtained results it can be concluded that the vitamin C levels studied C (100; 150 and 200ppm) were not enough to avoid losses on egg quality during 28 days of storage at room temperature $\left(26.7 \pm 2.2^{\circ} \mathrm{C}\right.$ and $60 \pm 5 \%$ moisture), in general, independent of the used vitamin $\mathrm{C}$ level. Brown eggs presented a superior quality than white eggs..

\section{5 - REFERENCES}

[1] CHENG, T.K., COON, C.N., HAMRE, M.L. Effect of environmental stress on the ascorbic acid requirement of laying hens. Poultry Science, Savoy, v. 69, n. 5, p. 774-80, 1990.

[2] HANS, G., MANN, S. Effects of supplementing of different levels of ascorbic acid on the performance on commercial 
laying hens. Fourtyth Western Poultry Disease Conference, Acapulco, México, 24 a 25 april, p.162-167, 1991. Proceedings.

[3] HERRICK, R.B., NOCKELS, C.F. Effect of a high level of ascorbic acid on egg quality. Poultry Science, Savoy, v. 48, p.1518$19,1969$.

[4] KECHIK, L.T., SYKES, A.H. Effect of dietary ascorbic acid on the performance of laying hens under warm environmental conditions. British Poultry Science, Abingdon, v. 15, p. 449-57,1974.

[5] NJOKU, P.C., NWAZOTA, A.O.U. Effect of dietary inclusion of ascorbic acid in solm oil on performance of laying hens in a hot tropical environment. British Poultry Science, Abingdon, v. 30, n. 4, p. 831-40, 1989.

[6] PEEBLES, E.D., BRAKE, J.D. Relationship of dietary ascorbic acid to broiler bueder performance. Poultry Science, Savoy, v. 64, n. 11, p. 2041-8, 1985.

[7] PEREK, M., KENDLER, J. Ascorbic acid as a dietary supplement for white Leghorn hens under conditions of climatic stress. British Poultry Science, Abingdon, v. 4, n. 2, p. 191-200, 1963.

[8] RODRIGUES, R.P., BERTECHINI, A.G., OLIVEIRA, B.L. Níveis de vitamina $D_{3}$ e suplementação de vitamina $C$ na dieta de poedeiras no segundo ciclo de produção. In: Conferência Apinco de Ciência e Tecnologia Avícola, 1995, Curitiba, p. 37-8.
[9] SOUZA, P.A., SOUZA, H.B.A., BROGNONI, E., ROCHA, O.E. Influência da idade da ave sobre a qualidade do ovo. Científica, São Paulo, v. 22, p. 217-226, 1994.

[10] SOUZA, P.A., SOUZA, H.B.A., BARBOSA, J.C., GARDINI, C.H.C., NEVES, M. Efeito da idade da galinha na qualidade dos ovos mantidos sob condições de ambiente. Ciênc. Tecnol. Aliment., Campinas, v. 17, n. 1, p. 49-52, 1997.

[11] SULLIVAN, T.W., KINGAN, J.R. Effect of dietary calcium level, calcium lactate, and ascorbic acid on production of s.c. White Leghorn hens. Poultry Science, Savoy, v. 41, p. 1596-602, 1962.

[12] TSERBENE-GOUSE, A.S., GIANNADOPOULOS, A.L., HRESTAKE, E. The effect of dietary vitamin $C$ on performance and egg quality of laying hens. Bulletin of Hellenic Veterinary Medical Society, v. 43, n. 4, p. 2338, 1992.

[13] WHITEHEAD, C.C., MITCHEL, M.A., NJOKU, P.C. Effects of ascorbic acid on egg yolk and shell precursors in heatstressed laying hens. $2^{\text {nd }}$ Symposium Ascorbic Acid in Domestic Animals, Kastause Ittingen, Switzerland, $9^{\text {th }}$ $12^{\text {th }}$ October, p. 262-269, 1990. Proceedings.

\section{6 - ACKNOWLEDGEMENTS}

The authors thank the received financial support from FAPESP (Foundation for the Advancement of Scientific Research of the State of São Paulo) for the development of the work. 